\title{
亂 KOMPARATIVNA ANALIZA PROTIVOKLOPNIH SISTEMA KORIŠĆENJEM AHP METODE
}

\author{
Marko Radovanović* \\ Vojska Srbije \\ Aca Ranđelović, Aleksandar Milić \\ Univerzitet odbrane u Beogradu, Vojna Akademija
}

U radu su prikazani i opisani protivoklopni sistemi u operativnoj upotrebi pojedinih armija sveta i Vojske Srbije sa njihovim taktičko-tehničkim i borbenim karakteristikama. Primenom višekriterijumskog odlučivanja i metode AHP izvršena je analiza dobijenih rezultata i izveden zaključak o stepenu efikasnosti protivoklopnih sistema, sa predlogom uvođenja određenog sredstva u operativnu upotrebu u Vojsku Srbije, a sa ciljem modernizacije i opremanja pešadijskih jedinica.

Ključne reči: protivoklopni sistem, višekriterijumsko odlučivanje, metoda AHP, protivoklopna vođena raketa

Dojava i razvoj oklopnih borbenih vozila rezultat je međusobne povezanosti nauke i tehnike i uslovila je iznalaženje i razvoj sredstava čiji je zadatak efikasno neutralisanje i uništavanje oklopnih borbenih vozila. Taktika savremenih borbenih dejstava zahteva uspešno vođenje protivoklopnih dejstava ${ }^{1}$ na srednjim i velikim daljinama. Protivoklopni raketni sistemi vatrene zadatke u najvećoj meri realizuju neposrednim gađanjem, ali postoje i savremeniji protivoklopni raketni sistemi koji svoje vatrene zadatke realizuju posrednim gađanjem. Pri neposrednom gađanju uvećan je rizik da protivoklopno sredstvo koje ga ostvaruje bude lakše otkriveno i izloženo vatri neprijatelja. Savremena borbena dejstva zahtevaju opremanje vojnika pešadije takvim tipom oružja koje je u stanju da neutrališe teško oklopljena vozila sa znatno veće (i bezbednije) udaljenosti i to prvim projektilom, a isto tako da to oružje poseduje i mogućnost gađanja iz prostorije i na malim daljinama, zbog dejstva u urbanoj sredini.

$U$ radu su prikazani protivoklopni raketni sistemi i njihove taktičko-tehničke karakteristike i izvršena je njihova komparativna analiza sa ciljem iznalaženja protivoklopnog raketnog sistema sa najvećim stepenom efikasnosti, a u zavisnosti od taktičko-tehničkih karakteristika. Uporedna analiza izvršena je upotrebom metoda višekriterijumskog odlučivanja.

\footnotetext{
* MA Marko Radovanović: ORCID ID https://orcid.org/0000-0002-9866-9639 .

${ }^{1}$ Protivoklopna dejstva (POD) predstavljaju sadržaj borbenih dejstava i definisana su kao "skup borbenih dejstava, postupaka i mera koje se preduzimaju radi uništavanja oklopnih i mehanizovanih snaga i sredstava protivnika, usporavanja njihovih dejstava i slabljenja njegove udarne i vatrene moći". [7]
} 


\section{Protivoklopni raketni sistemi u svetu}

Nakon Drugog svetskog rata dinamično su se razvijali protivoklopni raketni sistemi i oni danas beleže razvoj tri generacije protivoklopnih sistema. Protivoklopni sistemi I generacije „MCLOS“ (Manual Command to Line of Sight)(Slika 1.) predstavljaju sistem POVR sa ručnim vođenjem. Kod ovih sistema, operator i uređaji na lansirnom mestu su angažovani sve vreme leta rakete. Operator, golim okom ili posredstvom nišana, prati i cilj i raketu. U skladu sa uočenim odstupanjem putanje rakete od nišanske linije usmerene na cilj, metodom poklapanja tri tačke, operator-raketa-cilj, pokreće komandnu palicu uređaja za vođenje kako bi se poništilo pomenuto odstupanje. Obuka i održavanje utreniranosti operatora ovih sistema su izuzetno skupi i dugotrajni.

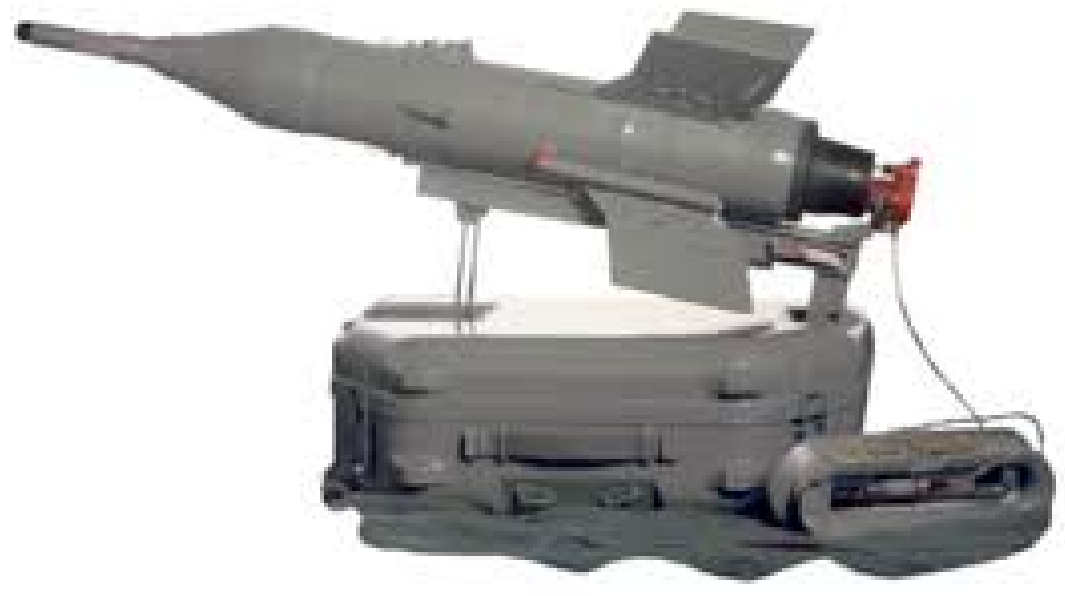

Slika 1 - PORS I generacije

Protivoklopni sistem II generacije „SACLOS“ (Semi-Automatic Command to Line Of Sight)(Slika 2) je sistem POVR sa poluautomatskim vođenjem. Slično kao kod sistema I generacije, i ovde su operator i uređaji na lansirnom mestu angažovani sve vreme leta rakete, ali je učinjen i kvalitativan skok u načinu angažovanja operatora. Njegov zadatak je samo da drži krst končanice nišana usmeren u pravcu cilja, ne vodeći uopšte računa šta se događa sa raketom. Sve ostalo odrađuje sistem vođenja. Zbog znatno redukovane i pojednostavljene uloge operatora, obuka je jeftinija i brža. Takođe, praktično uklanjanjem učestvovanja čoveka u procesu vođenja otvaraju se mogućnosti za razvoj sistema POVR sa znatno boljim performansama (veća verovatnoća pogađanja, veći domet i veća brzina leta rakete). Kod ovih sistema verovatnoća pojave greške u toku gađanja od strane operatora je smanjena u odnosu na sisteme sa ručnim vođenjem. 


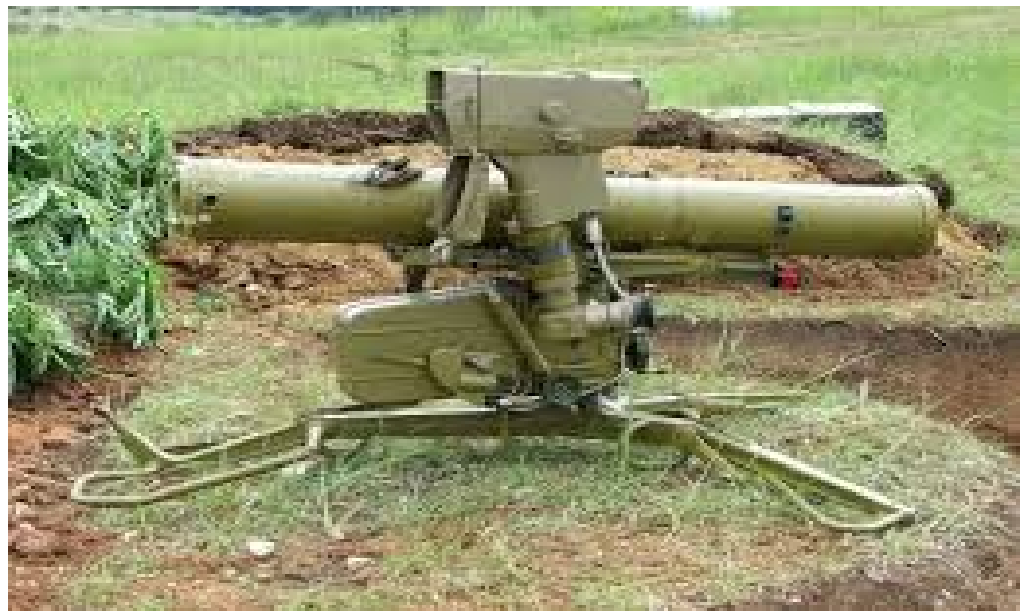

Slika 2 - PORS /l generacije

Protivoklopni sistem III generacije je sistem POVR koji radi na principu "ispali i zaboravi (fire and forget)" (Predict line of sight) Slika 3. Nakon lansiranja rakete, nema potrebe za angažovanjem operatora ili uređaja van rakete. Predstavljaju tehnološki vrhunac i najsofisticiranija sredstva. $U$ bojnoj glavi projektila instalirane su kamere, termalni tragači, IC zraci, laserski zraci i brojni prijemnici i emiteri signala koji omogućavaju izuzetno tačno i precizno samovođenje rakete, gde je ljudski faktor u potpunosti isključen.

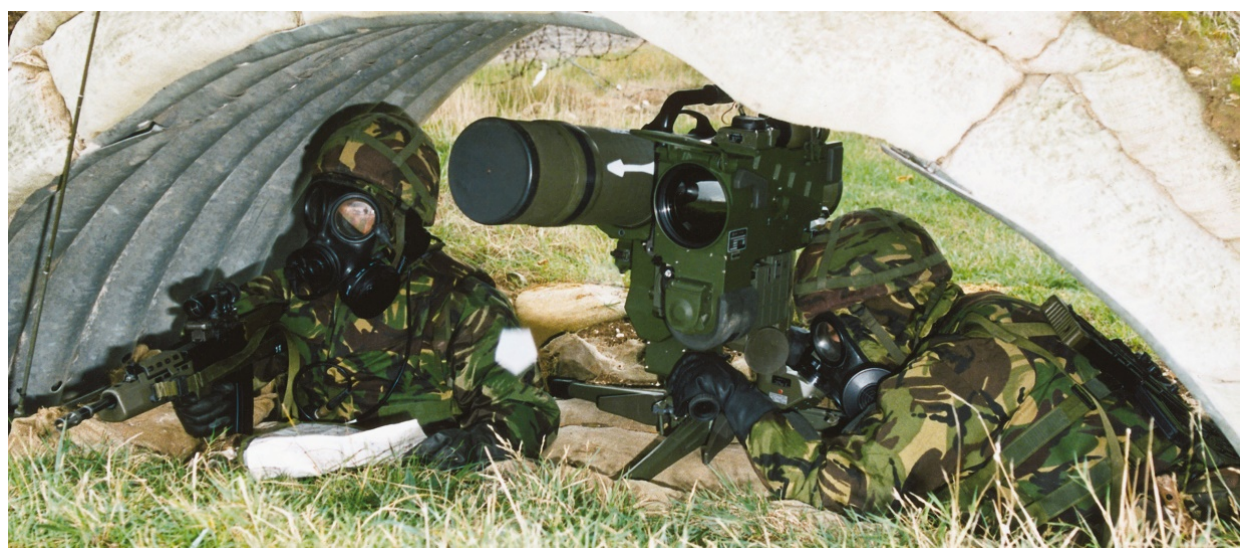

Slika 3 - PORS III generacije

Operater može biti svaki vojnik pešadije, jer je dužina trajanja obuke svedena na minimum, kao i verovatnoća pojave greške od strane operatora u toku gađanja. U naoružanju se nalaze od početka 21. veka.[35] 
U ovom delu rada analizirani su protivoklopni sistemi // i III generacije, a koji se nalaze u operativnoj upotrebi. To su sistemi TRIGAT (Third generation Anti-Tank) srednjeg dometa (MR - Medium range), TOW 2, HOT 2T, BIL 2, ERYX, KONKURS, KORNET, MATIS. Taktičko-tehničke karakteristike ovih modela prikazane su u tabeli 1 , na osnovu kojih je izvršena komparativna analiza.

Tabela 1 - Karakteristike PORS u naoružanju stranih oružanih snaga

\begin{tabular}{|c|c|c|c|c|c|c|c|c|c|}
\hline & $\begin{array}{c}\text { маса } \\
\text { система } \\
(\mathrm{kg})\end{array}$ & $\begin{array}{c}\text { маса } \\
\text { ракете } \\
\text { (kg) }\end{array}$ & тип ракете & $\begin{array}{c}\text { калибар } \\
(\mathrm{mm})\end{array}$ & $\begin{array}{c}\text { максимални } \\
\text { домет (m) }\end{array}$ & $\begin{array}{c}\text { минимални } \\
\text { домет (m) }\end{array}$ & $\begin{array}{c}\text { пробојност } \\
\text { (mm) }\end{array}$ & тип вођења & $\begin{array}{c}\text { могућност } \\
\text { гађања из } \\
\text { просторије }\end{array}$ \\
\hline ТРИГАТ МР & 45,2 & 21 & $\begin{array}{c}\text { тандем- } \\
\text { кумулативна }\end{array}$ & 150 & 4000 & 60 & $1000+$ EPA & аутоматски & да \\
\hline Бил 2 & 36 & 10,8 & $\begin{array}{c}\text { тандем- } \\
\text { кумулативна }\end{array}$ & 150 & 2200 & 150 & $550+$ EPA & полуаутоматски & не \\
\hline TOW 2A & 93 & 22,6 & $\begin{array}{c}\text { тандем- } \\
\text { кумулативна }\end{array}$ & 150 & 3750 & 65 & $800+E P A$ & полуаутоматски & не \\
\hline хот 3 & 24 & 6,48 & $\begin{array}{c}\text { тандем- } \\
\text { кумулативна }\end{array}$ & 150 & 4300 & 75 & 1250+EPA & полуаутоматски & не \\
\hline KOPHET & 19 & 27 & $\begin{array}{c}\text { тандем- } \\
\text { кумулативна и } \\
\text { термобарична }\end{array}$ & 152 & 5500 & 100 & $1200+E P A$ & аутоматски & да \\
\hline МЕТИС 2M & 24,5 & 13,8 & $\begin{array}{c}\text { тандем- } \\
\text { кумулативна }\end{array}$ & 130 & 1500 & 90 & $900+E P A$ & полуаутоматски & да \\
\hline КОНКУРС & 38 & 14,5 & кумулативна & 125 & 4000 & 70 & 800 & полуаутоматски & не \\
\hline ERYX & 15,8 & 9,8 & $\begin{array}{c}\text { тандем- } \\
\text { кумулативна }\end{array}$ & 135 & 600 & 25 & $900+E P A$ & аутоматски & да \\
\hline
\end{tabular}

Projekat protivoklopnog raketnog sistema TRIGAT realizovan je u dva modela: TRIGAT srednjeg dometa (MR (Medium range) TRIGAT) i TRIGAT dugog dometa (LR (Long range) TRIGAT ) koji je namenjen da se montira na vozila ili helikopter.

Sistem TRIGAT srednjeg dometa poseduje tandem-kumulativnu bojnu glavu sa 40milimetarskim pretpunjenjem i osnovnim kalibrom $150 \mathrm{~mm}$. Sa ovim sistemom moguće je gađanje iz zatvorenih prostorija. Raketa se vodi pomoću snopa impulsnog radara koji je modulisan prema vremenu i prostoru. Laserski prijemnik se nalazi u zadnjem delu rakete, što omogućava zaštitu od neprijateljskog elektronskog ometanja. Upotrebljava IC CDD detektor nove generacije. [1]

Protivoklopni sistem francuske proizvodnje ERYX, pripada II generaciji protivoklopnih raketnih sistema. Poseduje tandem-kumulativnu bojnu glavu sa pretpunjenjem kalibra $25 \mathrm{~mm}$ i osnovnim punjenjem kalibra $135 \mathrm{~mm}$. Hibridni model ugrađen u raketu upravlja njenim letom. Ugradnjom CCD kamere u lanser i modularne IC 0,9 $\mu \mathrm{m}$ ksenonske lampe ugrađene u raketu. Ovaj projektil upotrebljava tzv. „meko lansiranje“, što stvara mogućnost upotrebe u urbanoj sredini i gađanje iz zatvorenih prostorija. Brzina pri lansiranju je mala $(18 \mathrm{~m} / \mathrm{s})$, što omogućeno potisnim vektorima ugrađenim u raketu. Tokom leta razvija brzinu od $245 \mathrm{~m} / \mathrm{s}$.[15]

Protivoklopni raketni sistem HOT (High-subsonic Optically-guided Tube-Launched) predstavlja sistem druge generacije. Modernizovani model sistema HOT predstavlja model HOT - 2T, čija je konstrukcija modelovana na taj način da bude efikasna protiv reaktivnog 
oklopa. ${ }^{2}$ Poseduje tandem-kumulativnu bojnu glavu, dok je otpornost na elektronsko ometanje neprijatelja postignuta uvođenjem jednog IC CCD video goniometra od 0,9 $\mu \mathrm{m}$. Lansira se iz cevi, vodi uređajem za osmatranje, a komande se prenose preko mikrokabla. Postoji u više varijanti HOT, HOT 2, HOT 3 (Početna oznaka HOT 2T) i HOT 2MP. [21]

Veoma efikasan protivoklopni sistem švedske proizvodnje BILL (org. BILL), je prvi raketni sistem u svetu koji za gađanje cilja upotrebljava OTA (Overfly Tank Attack), što znači da se projektil kreće standardnom horizontalnom trajektorijom, ali umesto da direktno pogodi metu, on preleće metu i detonira bojnu glavu na gornjem delu oklopa koji je na tom mestu znatno tanji. Sistem vođenja je SACLOS, a signal se prenosi kablom i veoma je dobro zaštićeno od elektronskog ometanja neprijatelja. Modernizovana varijanta ovog sistema BILL-2 u raketi poseduje dva na niže usmerena kumulativna projektila. [15]

Protivoklopni sistem TOW (Tube-Launched Optical tracked Wire guided) od svog nastanka do danas je proizveden u velikom broju modifikacija. Ovaj sistem se nalazi u naoružanju četrdesetak zemalja, što govori o njegovoj efikasnosti. Model TOW 2A poseduje tandem-kumulativnu bojnu glavu, koja se aktivira iznad cilja i ima automatizovanu korekciju cilja. Princip rada kao kod sistema BILL, uz upotrebu OTA modela. Pripada grupi teških protivoklopnih sistema jer je masa rakete $22,6 \mathrm{~kg}$, a celokupnog sistema $93 \mathrm{~kg}$.

KORNET 9M133 protivoklopni raketni sistem sastavljen je od: lansera sa nišanomtragačem i mehaničkim praćenjem cilja, termičkog nišana i vođene rakete u transportnim lansirnim kontejnerima. Ovaj sistem poseduje veoma visoku probojnost koja iznosi i do $1200 \mathrm{~mm}$ plus ERA.[12] Raketa se vodi pomoću kodiranog laserskog snopa. Ima dve vrste bojnih glava i to: tandem-kumulativnu i razorno zapaljivu (termobarična sa aerosolnim eksplozivom, čija je namena uništavanje utvrđenih objekata). ${ }^{3}$ KORNET sistem je ruske proizvodnje i najčešće ga koriste bivše sovjetske republike i države koje podržava Ruska Federacija.

Ruski protivoklopni sistem 9K115 METIS, je sistem srednjeg dometa. Modernizovana verzija ovog sistema u svojoj upotrebi poseduje dve vrste raketa i to sa tandem-kumulativnom bojnom glavom i termobaričnu sa aerosolnim eksplozivom. Modernizovana varijanta METIS-M ima poluautomatski sistem vođenja putem mikrokabla, dok je nišan termalni. Ovaj sistem poseduje visoku probojnost koja iznosi $900 \mathrm{~mm}$ čelika plus ERA. Prednost ovog sistema je i mogućnost upotrebe u urbanoj sredini jer može da gađa i iz zatvorene prostorije.

Protivoklopni raketni sistem 9K113 KONKURS namenjen je za protivoklopnu borbu na srednjim daljinama. Prema klasifikaciji u zavisnosti od sistema vođenja pripada II generaciji protivoklopnih sistema „SACLOS“, sistem vođenja je poluautomatski putem mikro kabla. Poseduje indikator svetlosnih smetnji koji otkriva neprijateljske elektromagnetne talase. U pojedinim izvorima navedena preciznost ovog sistema koja iznosi $90 \%$.

Svi protivoklopni sistemi poseduju modifikovane modele koji se montiraju na vozila i upotrebljavaju se kao protivoklopno lansirno oruđe na vozilu (POLO) [22], čime se povećava zaštita posluge, veća je verovatnoća pogađanja, brže je posedanje i promena vatrenog položaja, moguća je ugradnja sistema za upravljanje vatrom i komandno informacionog sistema.

\footnotetext{
${ }^{2}$ ERA - eksplozivni reaktivni oklop (ERA - explosive reactive armour)

${ }^{3}$ Ovaj protivoklopni raketni sistem se izuzetno pokazao u Drugom libanskom ratu.
} 


\section{Protivoklopni raketni sistemi u naoružanju Vojske Srbije}

U naoružanju Vojske Srbije nalaze se protivoklopni raketni sistem 9K11 „MALjUTKA“ i 9K111 „FAGOT“. Sistem 9K11 pripada I generaciji protivoklopnih sistema, dok sistem 9K111 FAGOT pripada II generaciji protivoklopnih sistema. Sistemi koji se nalaze u naoružanju Vojske Srbije su u značajnoj meri prevaziđeni. Vreme proizvodnje (šezdesete i sedamdesete godine prošlog veka) ne omogućavaju im da prate savremeni razvoj oklopnih sredstava. Protivoklopne mogućnosti protivoklopnih vođenih raketa u naoružanju Vojske Srbije su male [14], a to je još jedan od razloga zbog čega je neophodna zamena postojećih protivoklopnih sistema i uvođenje savremenih protivoklopnih raketnih sistema kako bi jedinice Vojske Srbije mogle uspešno da se suprotstave i najsavremenijim oklopnim sredstvima, sa što većom efikasnošću. U tabeli 2 prikazane su karakteristike PORS koji se nalaze u naoružanju Vojske Srbije.

Tabela 2 - Karakteristike PORS u naoružanju Vojske Srbije

\begin{tabular}{|c|c|c|c|c|c|c|c|c|c|}
\hline & $\begin{array}{c}\text { маса } \\
\text { система } \\
(\mathrm{kg})\end{array}$ & $\begin{array}{c}\text { маса } \\
\text { ракете } \\
(\mathrm{kg})\end{array}$ & тип ракете & $\begin{array}{c}\text { калибар } \\
(\mathrm{mm})\end{array}$ & $\begin{array}{c}\text { максимални } \\
\text { домет (m) }\end{array}$ & $\begin{array}{c}\text { минимални } \\
\text { домет (m) }\end{array}$ & $\begin{array}{c}\text { пробојност } \\
(\mathrm{mm})\end{array}$ & $\begin{array}{c}\text { могућност } \\
\text { гађања из вођења } \\
\text { просторије }\end{array}$ \\
\hline МАљУтКА & 20,4 & 10,9 & кумулативна & 125 & 3000 & 500 & 460 & ручно & пе \\
\hline ФАГОТ & 22,5 & 13,4 & кумулативна & 120 & 2500 & 75 & 400 & полуаутоматски & да \\
\hline
\end{tabular}

Protivoklopni lansirni komplet 9K11 MALjUTKA „MCLOS“ sistema vođenja metodom tri tačke putem mikro kabla. Omogućava gađanje od 500 do 3000 metara. Ovaj protivoklopni sistem se može postaviti i na vozilo. Koristi raketu kalibra $125 \mathrm{~mm}$ kumulativnog dejstva. Srednja brzina leta rakete je $120 \mathrm{~m} / \mathrm{s}$. Problem kod ovog sistema predstavlja kasno prihvatanje rakete i mogućnost gađanja tek od $500 \mathrm{~m}$. Verovatnoća pogađanja protivoklopnim sistemom MALjUTKA iznosi 70\%.[23]

Protivoklopni raketni sistem 9K111 FAGOT Ruske proizvodnje ima „SACLOS“, sistem vođenja koji je poluautomatski putem mikro kabla. Koristi raketu kumulativnog dejstva i u svom kompletu ima indikator svetlosnih smetnji koji otkriva neprijateljske elektromagnetne talase. Brzina leta rakete je $186 \mathrm{~m} / \mathrm{s}$. Poslugu protivoklopnog sistema 9K111 čine tri člana. Verovatnoća pogađanja protivoklopnim sistemom FAGOT iznosi 80\%.[24]

\section{Metoda Analitički hijerarhijski proces (AHP)}

Tomas Sati (Thomas Saaty) je sedamdesetih godina XX veka razvio metodu analitički hijerarhijski proces (AHP) (Analytic Hierarchy Process), koja pripada metodi višekriterijumskog odlučivanja. Do danas ova metoda je doživela veliki broj modifikacija $[3,4,20,32,33]$, ali se u nekim slučajevima i dalje koristi u svom izvornom obliku kako u pojedinačnom [2] tako i grupnom odlučivanju [11]. Primenjuje se u analizi odlučivanja i donošenju odluka u rešavanju kompleksnih problema čije elemente čine ciljevi, kriterijumi, podkriterijumi i alter- 
native. Idealna je u slučajevima kada u odlučivanju učestvuje veći broj donosioca odluke i kada se odlučivanje zasniva na većem broju kriterijuma u višestrukim vremenskim periodima. Realizuje se razlaganjem (struktuiranjem) problema u hijerarhije, definisanje dodeljujućih težina kriterijumima, formiranjem matrica komparacije parova, radi određivanja normalizovanih težina. Dodeljene težine se koriste za evaluaciju atributa na najnižem nivou celokupne hijerarhije. Proces donošenja odluke je kompleksan zbog pojave konkurentnih i konfliktnih ciljeva među alternativama i kriterijumima. Autor metode je naglasio da se praksa odlučivanja najčešće bavi ponderisanim alternativama, koje zadovoljavaju skup željenih ciljeva. Potrebno je izabrati alternative koje će na najbolji mogući način zadovoljiti celokupni skup ciljeva. Proces modelovanja obuhvata četiri faze [28]: /1/ struktuiranje problema, /2/ prikupljanje podataka, /3/ ocenjivanje relativnih težina i /4/ određivanje rešenja problema.

Faza strukturiranja problema se sastoji od dekomponovanja kompleksnog problema odlučivanja u seriju hijerarhija gde svaki nivo predstavlja manji broj upravljivih atributa. Oni se potom dekomponuju u drugi skup elemenata koji odgovara sledećem nivou i tako redom. Kod druge faze primene metode lica koja učestvuju u formiranju odluke dodeljuje relativne težine (ocene) kriterijumima čime se omogućava poređenje parova prema atributima jednog hijerarhijskog nivoa i to za sve nivoe celokupne hijerarhije uz primenu Skale devet tačaka (tabela 3).

Tabela 3 - Skala devet tačaka [27]

\begin{tabular}{|c|c|}
\hline СКАЛА & ОБЈАШНЕНЕ РАНГИРАНА \\
\hline 9 & апсолуто најзначајније/најпожељније \\
\hline 8 & веома снажно ка апсолутно најзначајнијем \\
\hline 7 & веома снажно ка веома значајном/пожељном \\
\hline 6 & снажно ка веома снажном \\
\hline 5 & снажније више значајно/пожељни \\
\hline 4 & слабије ка више снажнијем \\
\hline 3 & слабије више значајно/пожељније \\
\hline 2 & подједнако ка слабијем вишем \\
\hline 1 & подједнако значајно/пожељно \\
\hline 0,5 & подједнако ка слабијем мањем \\
\hline 0,33 & слабије мање значајни/пожељно \\
\hline 0,25 & слабије ка снажно мањем \\
\hline 0,2 & снажно мање значајно/пожељно \\
\hline 0,17 & снажно ка веома снажно мањем \\
\hline 0,14 & изузетно снажно мање значајно/пожељно \\
\hline 0,13 & веома снажно ка апсолутно мањем \\
\hline 0,11 & апсолутно најмање значајно/пожељно \\
\hline
\end{tabular}

Ovako hijerarhijsko strukturiranje bilo kog problema odlučivanja je efikasan put suočavanja sa kompleksnošću realnih problema i identifikovanja značajnih atributa u cilju dostizanja sveukupnog cilja problema. Samim tim AHP metoda poseduje i pruža izuzet- 
nu fleksibilnost pri pomoći kod upravljačkih procesa odlučivanja. Metoda AHP omogućava da se realizacija zavisnosti-nezavisnosti između atributa dekomponuje u različite hijerarhijske nivoe.[34] Radi lakše primene metode i bržeg dolaska do potrebnih rezultata razvijen je originalni softver iz klase sistema za podršku odlučivanja Expert Choice ${ }^{4}$ koji podržava odlučivanje primenom metode „AHP“. [29]

Primena višekriterijumske analize i navedene metode u značajnoj meri je zastupljena u procesu odlučivanja u raznim oblastima. [30,31]. O podršci odlučivanju u vojnoj problematici svedoče različiti radovi $[5,9,10,14,13,16,17]$ i udžbenici [6].

\section{Komparativna analiza protivoklopnih raketnih sistema upotrebom AHP metode}

Analizom literature iz oblasti teorije gađanja i balistike, prikupljenim i obrađenim rezultatima sprovedenih gađanja, istraživanja i stručnosti, kao i prikupljenih iskustava pripadnika Vojske Srbije definisani su Kriterijumi (masa protivoklopnog sistema i rakete, kalibar, maksimalni efikasni domet sistema, minimalni daljina gađanja, probojnost, sistem vođenja, vrsta rakete i mogućnost gađanja iz zatvorenih prostorija) na osnovu kojih se ocenjuje efikasnost različitih sistema.

Masa rakete i protivoklopnog sistema ostvaruje neposredan uticaj na pokretljivost i mogućnost prenosa vatre. Protivoklopni sistemi manje mase omogućavaju veću pokretljivost posada (brža promena vatrenog položaja) i praktičniji su za rad. Masa rakete i sistema direktno utiče na broj poslužilaca. Veći broj poslužilaca povećava i mogućnost otkrivanja, a obrnuto je proporcionalan mogućnostima zaštite posluge. Potreba za manjom masom se obezbeđuje uvođenjem kompozitnih ili lakših materijala, kojima se obezbeđuju iste borbene karakteristike. Tako konstruisani PORS ne zahtevaju montiranje na motornim vozilima ili vazduhoplovima, za razliku od PORS veće mase.

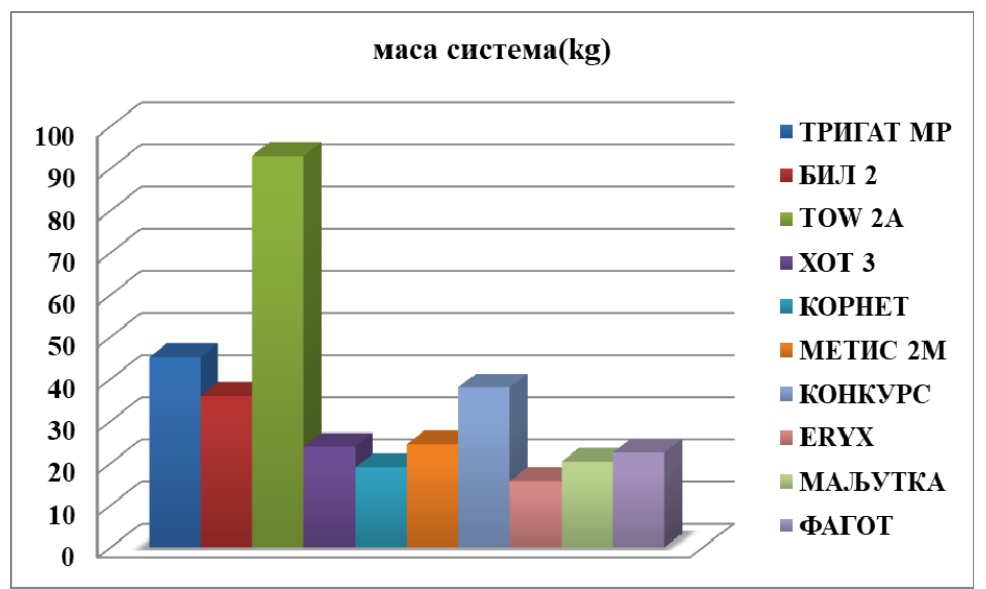

Grafikon 1 - Masa protivoklopnih raketnih sistema

\footnotetext{
${ }^{4}$ Softver Expert Choice, EC2000, 2000. Expert Choice Inc., Pittsburg, USA
} 
Kalibar predstavlja prečnik rakete u lanseru. Kalibar protivoklopne rakete ostvaruje neposredan uticaj na probojnost, i pod određenim uslovima kumulativni projektili mogu da probiju oklop debljine 5-10 kalibara eksplozivnog punjenja.

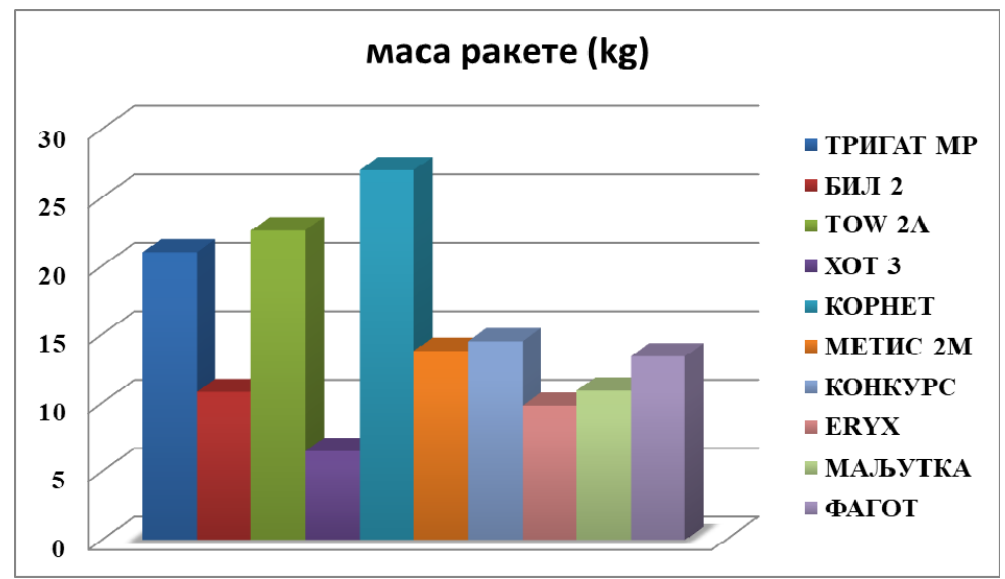

Grafikon 2 - Masa rakete PORS

Veći kalibar protivoklopne rakete, pod istim uslovima ostvaruje i veću probojnost. Kalibar protivoklopne rakete je najčešće u granicama od 125 do $155 \mathrm{~mm}$.

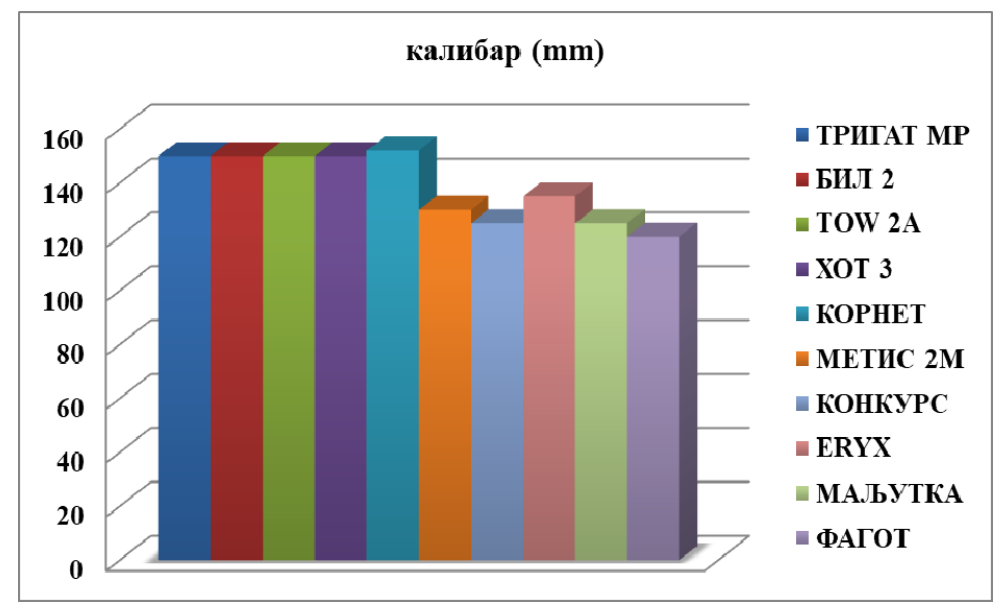

Grafikon 3 - Kalibar PORS

Efikasni domet predstavlja daljinu na kojoj je očekivano pogađanje cilja. Veći efikasni domet omogućava vođenje protivoklopnih dejstava na većim daljinama, čime se stvaraju mogućnosti za povećanjem stepena sigurnosti i zaštite za poslugu. 


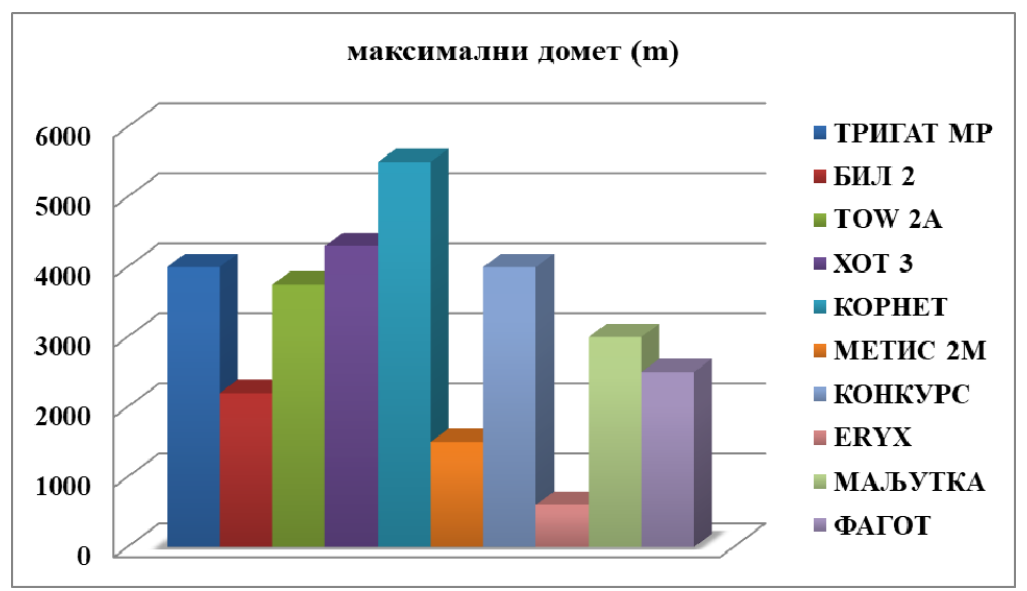

Grafikon 4 - Maksimalni domet rakete PORS

U vremenu kada se borbena dejstva najčešće izvode u urbanoj sredini, važno je ne zaboraviti da je mogućnost gađanja na malim daljinama. Navedena mogućnost je potrebna usled činjenica da će se PORS koristiti i u naseljenom mestu.

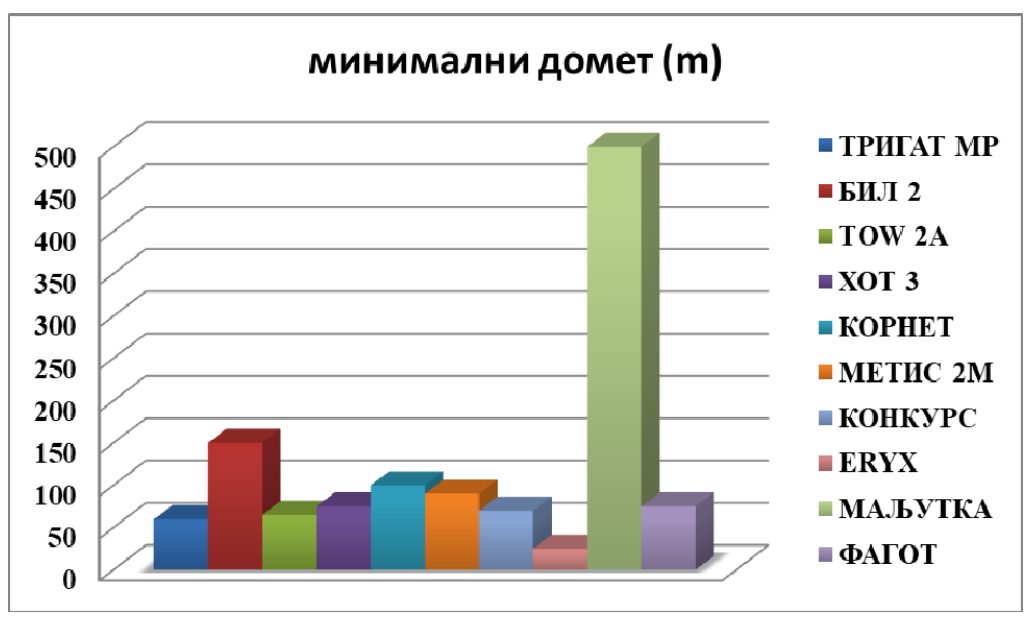

Grafikon 5 - Minimalni domet rakete PORS

Probojnost predstavlja borbenu osobinu koja ispoljava značajan uticaj na izvođenje protivoklopnih dejstava. Veća probojnost omogućava uspešno probijanje, neutralisanje i uništavanje oklopnog vozila. Savremeni projektili sa tandem - kumulativnom bojnom glavom omogućavaju probijanje oklopa koji poseduje aktivno-reaktivnu zaštitu, što stvara prednost u odnosu na klasične projektile sa kumulativnim dejstvom. 


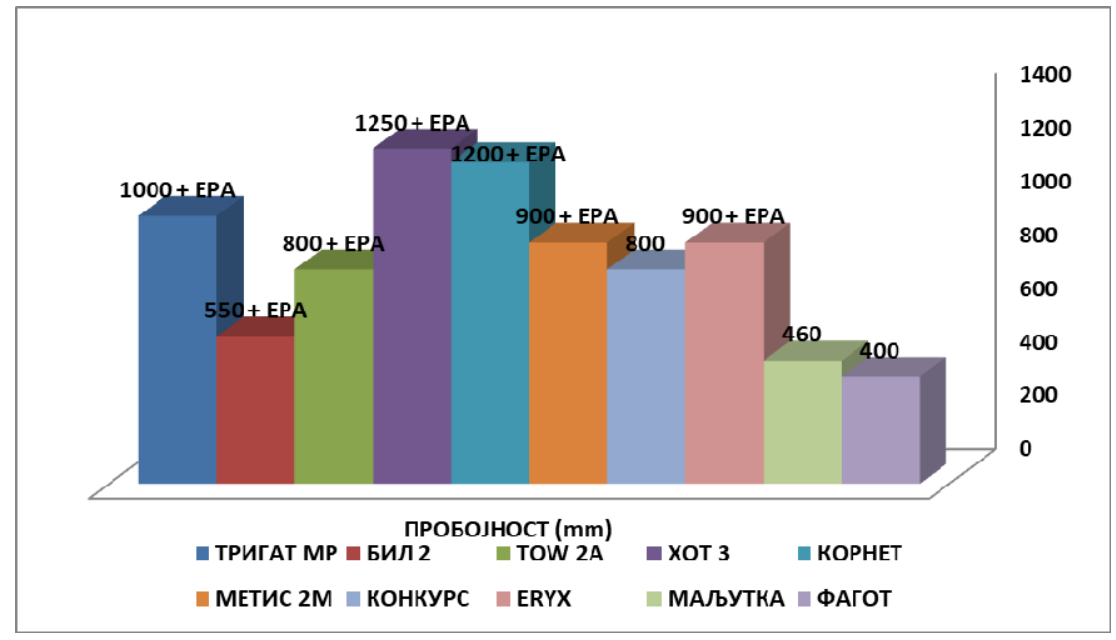

Grafikon 6 - Probojnost PORS

Sistem vođenja predstavlja karakteristiku projektila koja određuje i kojoj generaciji protivoklopnih sistema pripada. Prvoj generaciji PORS pripadaju sistem sa ručnim vođenjem (Manual Command to Line of Sight ( MCLOS)). Unapređeni sistemi koji pripadaju drugoj generaciji PORS su sistemi sa poluautomatskim vođenjem (Semi-Automatic Command to Line Of Sight (SACLOS)). Protivoklopni sistemi III generacije "ispali i zaboravi" (fire and forget) predstavljaju tehnološki vrhunac i najsofticiranija sredstva. Nakon lansiranja rakete, nema potrebe za angažovanjem operatora ili uređaja van rakete.

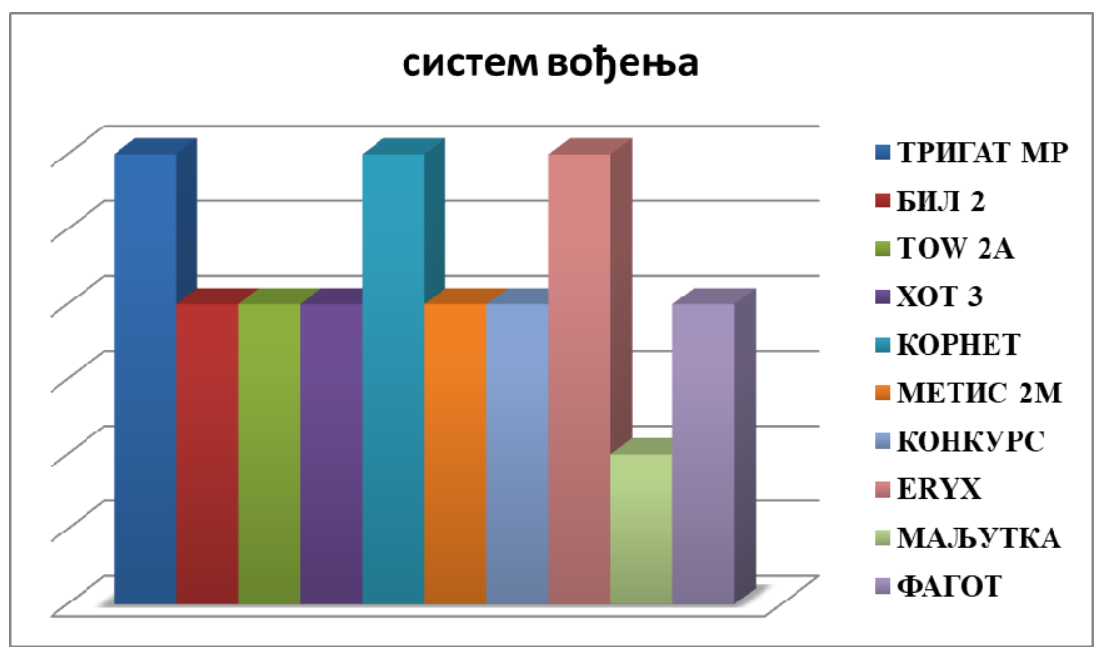

Grafikon 7 - Sistem vođenja PORS 
Borbena karakteristika protivoklopnih sistema koja karakteriše mogućnost gađanja iz zatvorenih prostorija ostvaruje neposredan i pozitivan uticaj na izvođenje protivoklopnih dejstava u urbanoj sredini. Različiti borbeni sukobi poslednjih decenija imaju zajedničku karakteristiku (prema lokaciji najvećeg broja sukoba) da se vode u urbanoj sredini. Samim time se nameće kao osnovni zahtev za izbor PORS navedena mogućnost. Protivoklopna sredstva koja mogu da gađaju iz zatvorene prostorije su u značajnoj prednosti (u odnosu na ona koja nemaju ili imaju manje sposobnosti za tu karakteristiku).

Eksperti iz predmetne oblasti su dodelili težine predloženim kriterijumima, koje su unet u program Expert Choice. Dobijene vrednosti su prikazane na slici 4.

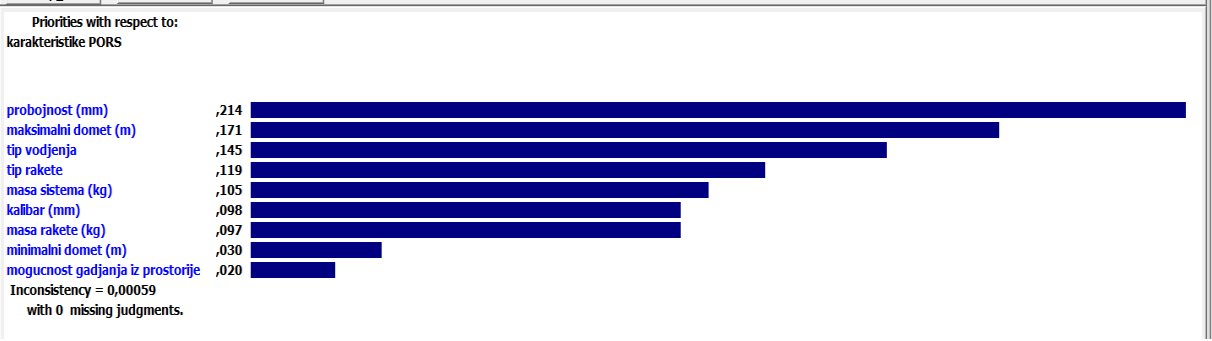

Slika 4 - Koeficijenti težine kriterijuma

Važna mogućnost metode i samog programa je predstavljena kroz mogućnost praćenja stepena konzistentnosti, čime se umanjuje mogućnost subjektivnosti donosioca odluke. Ukoliko je stepen konzistentnosti manji od 0,10 rezultat je dovoljno tačan i nema potrebe za korekcijama u poređenju i ponavljanju proračuna. U slučaju da je stepen konzistentnosti veći od 0,10 rezultat bi trebalo ponovo analizirati i ustanoviti razloge nekonzistentnosti.

Prednost programa je iskazana u mogućnosti prikaza zavisnosti vrednosti alternativa (u ovom slučaju različitih sistema PORS) od težinskih vrednosti kriterijuma u funkciji cilja. Radi lakšeg praćenja omogućen je istovremeni grafički i numerički prikaz dobijenih vrednosti (za navedene kriterijume) (slika 5).

\begin{tabular}{|c|c|c|}
\hline 1 & I国 + -_ slematues: Disitbuive mode & $E_{E}+ \pm$ \\
\hline 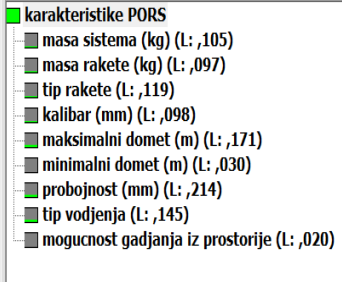 & \begin{tabular}{|l|} 
TRIGAT MR \\
BILL 2 \\
TOW 2A \\
HOT 3 \\
KORNET \\
METIS 2M \\
KONKURS \\
ERYX \\
MALJUTKA \\
FAGOT \\
\end{tabular} & $\begin{array}{l}.113 \\
.083 \\
.092 \\
.132 \\
.148 \\
.092 \\
.087 \\
.115 \\
.067 \\
.071\end{array}$ \\
\hline
\end{tabular}

Slika 5 - Model problema - Stablo kriterijuma, vrednosti težišnih koeficijenata kriterijuma i prioriteti alternativa 
Dobijeni rezultat, bez obzira na zadovoljstvo, potrebno je anali zirati $[18,19]$. Program omogućava izvršenje određenih analiza.

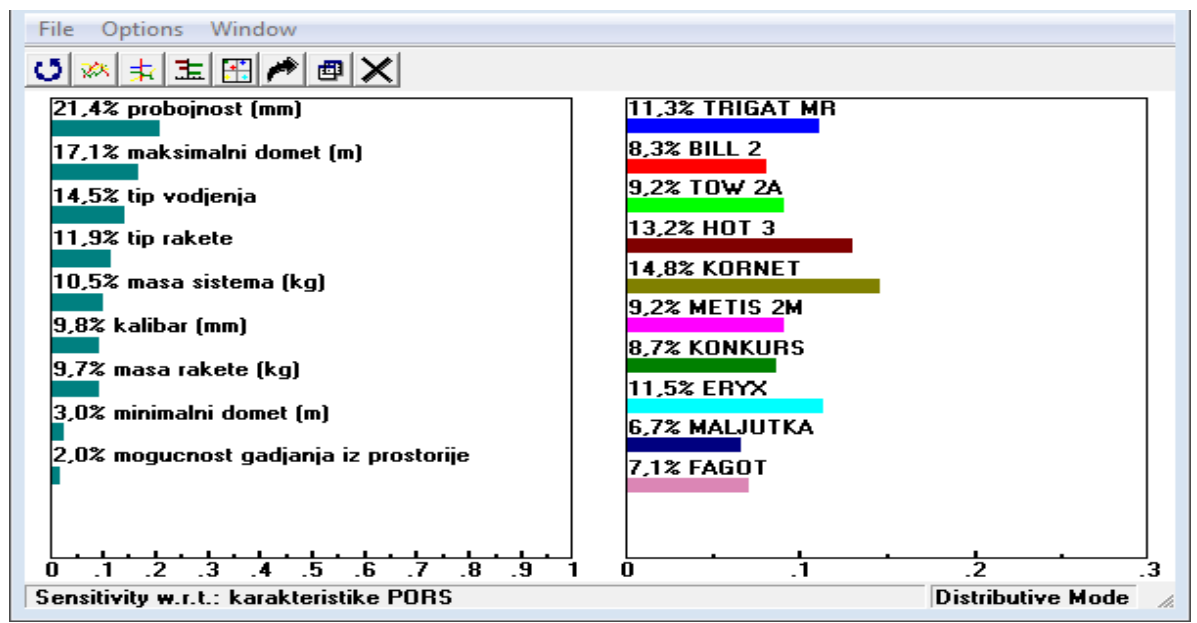

Slika 6 - Dinamička analiza osetljivosti rešenja dobijenog sintezom na nivou problema po kriterijumima

Dinamička analiza osetljivosti na nivou kriterijuma i na nivou karakteristika PORS kao funkcije cilja, prikazana je na slici 6 . Prilikom analize je moguće vršiti određene promene vrednosti kriterijuma i pratiti na koji način oni utiču na postojanost rezultata.

Dijagram osetljivosti prema performansama sistema (karakteristikama PORS) (Slika 7), omogućava praćenje uticaja pojedinih kriterijuma na trenutni i ukupni poredak alternative, čime se vrši izbor najpovoljnije alternative u odnosu na zadate kriterijume.

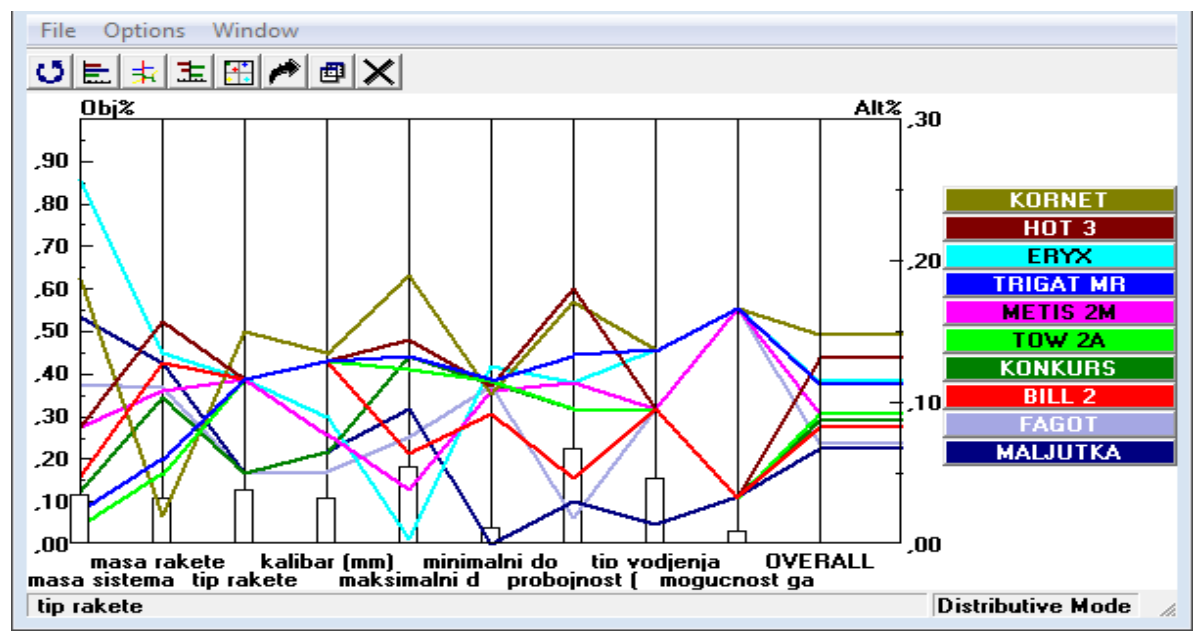

Slika 7 - Dijagram osetljivosti karakteristika PORS 
Pored prikazanih analiza prema ukupnim kriterijuma, moguće je vršiti poređenje određenih alternativa u parovima i pratiti rezultate prema zadatim kriterijumima.

Prioriteti alternativa po svakom kriterijumu dobijeni su na osnovu apsolutnih vrednosti kriterijuma po alternativama (Tabela 1 i 2). Rezultat sinteze problema ocene efikasnosti na osnovu karakteristika PORS dati su u vidu višekriterijumske rang liste alternativa (Slika 8).

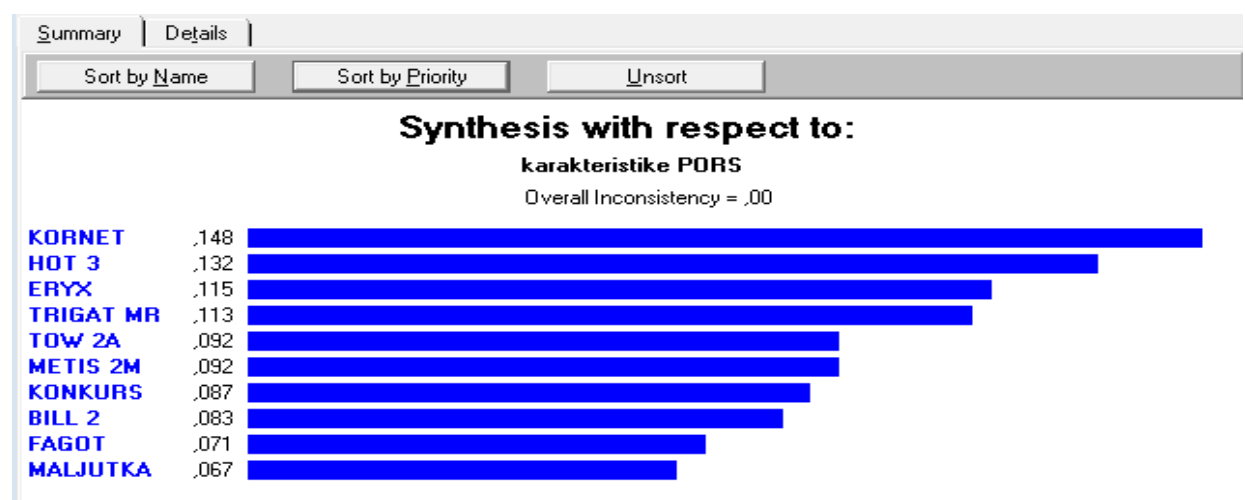

Slika 8 - Višekriterijumska rang lista efikasnosti na osnovu karakteristika PORS na nivou funkcije cilja

Analize rezultata dobijenih istraživanjima, kao i saznanja do kojih se došlo, pokazuju sledeće:

- Udeo kriterijuma na efikasnost protivoklopnih raketnih sistema uslovljena je: probojnost sa $21,4 \%$, maksimalni domet sa $17,1 \%$, tip vođenja sa $14,5 \%$, vrsta rakete sa $11,9 \%$, masa PORS sa $10,5 \%$, kalibar sa $9,8 \%$, masa rakete sa $9,7 \%$, zatim minimalna daljina gađanja sa $3 \%$ i mogućnost gađanja iz zatvorenih prostorija sa $2 \%$;

- protivoklopni raketni sistemi u naoružanju Vojske Srbije zauzimaju poslednja dva mesta liste višekriterijumske analize;

- analiza karakteristika efikasnosti PORS u naoružanju Vojske Srbije su znatno inferiornija u odnosu na PORS stranih armija;

- neophodna je modernizacija i opremanje protivoklopnih jedinica VS savremenim protivoklopnim raketnim sredstvima.

\section{Zaključak}

U radu su na osnovu tabelarnog prikaza iskazane borbene osobine protivoklopnih raketnih sistema II i III generacije koji se nalaze na upotrebi u pojedinim armijama sveta i protivoklopnih raketnih sistema koji se nalaze u naoružanju Vojske Srbije. Na osnovu poznatih podataka o borbenim osobinama i taktičko-tehničkim karakteristikama protivoklopnih sistema izvršena je komparativna analiza upotrebom AHP metode i metode softvera iz klase sistema za podršku odlučivanja Expert Choice a rezultati su prikazani kroz dijagrame. Na osnovu dobijenih rezultata izvršeno je rangiranje protivoklopnih raketnih sistema. Kao najefikasniji protivoklopni raketni sistem pokazao se sistem KORNET, koga prati sistem HOT 3, a na trećem mestu se nalazi sistem ERYX. 
Uporednom analizom taktičko - tehničkih karakteristika PORS srednjeg dometa koji su u operativnoj upotrebi mnogih stranih oružanih snaga, kao i protivoklopnih raketnih sistema na upotrebi u Vojsci Srbije, a imajući u vidu značaj izvođenja protivoklopnih dejstava u savremenom konceptu ratovanja dolazi se do zaključka da je neophodna hitna modernizacija i osavremenjavanje protivoklopnih sistema u jedinicama Vojske Srbije. Kao moguće rešenje (na osnovu iskazanih rezultata) za poboljšanje operativnih sposobnosti VS nameće se nabavka i opremanje protivoklopnog sistema KORNET.

Zahtevi koje postavljaju savremena borbena dejstva zahtevaju dalji razvoj i usavršavanje protivoklopnih raketnih sistema. Ubrzan je razvoj izdignutih platformi za protivoklopnu borbu, protivoklopnih sistema III i IV generacije, PORS na vozilima, protivoklopnih raketnih sistema velikog dometa sa laserskim vođenjem bez neposrednog vizuelnog kontakta sa ciljem (protivoklopni sistem domaće proizvodnje ALAS - Advanced Light Attack System). Kod ovih sistema vođenje je kombinovano na srednjem delu trajektorije i vođenje se ostvaruje pomoću inercijalne platforme koja raketu vodi u očekivanu zonu cilja. Dalji razvoj domaćeg protivoklopnog naoružanja trebalo bi nastaviti u ovom smeru, kako bi jedinice Vojske Srbije bile opremljene najsavremenijim protivoklopnim naoružanjem.

Opremanje novim najsavremenijim protivoklopnim naoružanjem bi mogao biti zadatak za nova istraživanja i radove. Istraživanja usmerena na problematiku izbora odlučujućih karakteristika protivoklopnih sredstava, kao i načina opremanja.

\section{Literatura}

[1] Арсић, С., (2002), Наоружање копнене војске, ВИЗ, Београд.

[2] Badi, I., Abdulshahed, A., (2019), Ranking the Libyan airlines by using full consistency method (FUCOM) and analytical hierarchy process (AHP), Operational Research in Engineering Sciences: Theory and Applications, Вол. 2, бр. 1, стр. 1-14.

[3] Božanić, D., Pamučar, D., Bojanić, D., (2015), Modification of the analytic hierarchy process (AHP) method using fuzzy logic: Fuzzy AHP approach as a support to the decision making process concerning engagement of the group for additional hindering, Serbian Journal of Management, Вол. 10, бр. 1, стр. 151-171.

[4] Božanić, D., Tešić, D., Milićević, J., (2018), A hybrid fuzzy AHP-MABAC model: Application in the Serbian Army - The selection of the location for deep wading as a technique of crossing the river by tanks, Decision Making: Applications in Management and Engineering, Вол. 1, бр. 1, стр. 143-164.

[5] Божанић, Д., Памучар, Д., Ђоровић, Б., Милић, А., Луковац, В.(2011), Примена fuzzy ahp методе на избор правиа дејства групе за допунско запречавање,, SYMOPIS 2011, Златибор, 556-559. страна, ISBN 978-86-403-1168-7.

[6] Боровић, С., Милићевић, М., (2001), Збирка задатака из одабраних области операционих истраживања, СШОНИД, УНИД, ВА, Београд.

[7] Војни лексикон, (1981), ВИЗ, Београд.

[8] Дамјановић, Д., (2013), Примена АХП методе на селекцију и евалуацију добављача, Мастер рад, Универзитет Сингидунум, Београд,

[9] Ђоровић, Б., (2003), Истраживање пројеката организационе структуре управних органа саобраћајне службе - докторска дисертација, Војна академија, Београд, 2003.

[10] Ђукић, Р., (1989), Рангирање алтернатива методом нормализације критеријумских фрункција на више нивоа, Научно-технички преглед, Вол XXXIX, Бр.6/1989. 
[11] Janković, A., Popović, M., (2019), Methods for assigning weights to decision makers in group AHP decision-making, Decision Making: Applications in Management and Engineering, Вол. 2, бр. 1, стр. 147-165.

[12] Јокић, Ж., Јотић, С., Лазић, Г., (2018), Анализа противоклопних ракетних система у циљу опремања јединица Војске Србије, 21. Међународна DQM конференција Управљање квалитетом и поузданошћу - зборник радова, Пријевор.

[13] Каровић, С., (2006), Условљеност организацијско-формацијске структуре артиљеријских јединица за подршку увођењем савремених технологија, докторска дисертација, ВА, Београд.

[14] Каровић, С., Пушара, М., Ристић, В., Комазец, Н. (2011) Аналитички хијерархијски процес као подршка одлучивању ангажовања снага у одбрамбеној операцији, (SYM-OP-IS 2011), Златибор, 588-591.

[15] Лазић, Г., Шиљак, 3., Јовандић, С., (2010), Противоклопни вођени пројектили Западне европе, Израела и Индије, ВТГ 4/10, Београд.

[16] Милић, А., Каровић, С., Славковић, Р., (2014), Очена модела за израду минских поља применом Аналитичког хијерархијског процеса, SYM-OP-IS 2014, Зборник радова, Дивчибаре, ISBN 978-86-7395-325-0, 469 - 472. страна.

[17] Милић, А., Памучар, Д., Божанић, Д., (2018), Вишекритеријумско одлучивање као подршка управљању пројектима (војним операцијама), 13. Међународна конференција „Ризик и безбедносни инжењеринг“, Копаоник.

[18] Pamučar, D., Božanić, D, Ranđelović, A., (2017), Multi-criteria decision making: An example of sensitivity analysis, Serbian Journal of Management, Вол. 12, бр. 1, стр. 1-27.

[19] Pamučar, D., Lukovac, V., Božanić, D., Komazec, N., (2018), Multi-criteria FUCOM-MAIRCA model for the evaluation of level crossings: case study in the Republic of Serbia, Operational Research in Engineering Sciences: Theory and Applications, Вол. 1, бр. 1, стр. 108-129.

[20] Петровић, И., Гордић, М., Канкараш, М., (2018), Фази - АХП приступ у вредновању критеријума за избор ракетног система за противваздухопловна дејства, Војно дело, Вол. 70 , бр. 2, стр. 298-308.

[21] Подаци о наоружању - Противоклопни вођени ракетни системи I, (2000), Ново издање свеске 6/1979. године, ВТИ, Београд.

[22] Подаци о наоружању - Противоклопни вођени ракетни системи II, (2000), Ново издање свеске 6/1979. године, ВТИ, Београд.

[23] Правило противоклопни ракетни систем 9К11, (1997), Новинско издавачка установа „Војска“, Београд.

[24] Правило противоклопни ракетни систем 9К111, (2000), ВИЗ, Београд.

[25] Радовановић, М., Ранћеловић, А., Репић, П., (2017), Anti-armor capabilities of an antiarmor platoon in defense, 8.th DQM International Conference Life Cycle Engineering and Managment - Proceedings, Пријевор.

[26] Радовановић, М., Ранђеловић, А.,(2018), Компаративна анализа противоклопних ракетних система, 21. Међународна DQM конференција Управљање квалитетом и поузданошћу - зборник радова, Пријевор.

[27] Saaty T. L., (1972) , An Eigenvalue Allocation Model for Priorization and Planning, Energy Management and Policy Center, University of Pennsylvania.

[28] Satty T.L., (1980), The Analytic Hierarchy Process, McGraw-Hill, New York.

[29] Softver Expert Choice, EC2000, 2000, Expert Choice Inc., Pittsburg, USA.

[30] Срђевић, Б., Зечевић, Т., (2003), АХП у групном одлучивању са потпуном и непотпуном информацијом, SYMOPIS 2003, Херцег Нови. 
[31] Срђевић, 3., Срђевић, Б., Поткоњак, С., Зорановић, Т., (2002), Алокација земљишта на биљне културе у условима наводњавања и одводњавања: вишекритеријумски прилаз помоћу аналитичког хијерархијског процеса (АХП), Мелиорације и пољопривреда, Пољопривредни фракултет, Нови Сад.

[32] Stanković, M., Gladović, P., Popović, V., (2019), Determining the importance of the criteria of traffic accessibility using fuzzy AHP and rough AHP method, Decision Making: Applications in Management and Engineering, Вол. 2, бр. 1, стр. 86-104.

[33] Chatterjee, P., Stević, Ž., (2019), A two-phase fuzzy AHP - fuzzy TOPSIS model for supplier evaluation in manufacturing environment, Operational Research in Engineering Sciences: Theory and Applications, Vol. 2, No. 1, pp. 72-90.

[34] Чупић М. и Сукновић М.,(2010), Одлучивање, ФОН, Београд.

\section{Интернет странице:}

[35] http://www.vti.mod.gov.rs 